\title{
2. The Battleground of Representation: From the Paris Commune to Nazism
}

\begin{abstract}
The first war documented in photographs was the Crimean War (1853-56). However, the first social revolution recorded photographically was the Paris Commune (18 March28 May 1871). Starting as an uprising by the National Guard after Paris's surrender in the Franco-Prussian War, the Paris Commune erupted first and foremost as a reaction to the possible establishment of a monarchy. It was the first revolution in history that gathered a wide stratum of workers, and it aimed to secularise and abolish Church property, cancel workers' debts, eliminate night shifts at work, ban the fining of workers, aspire to worker self-management and establish social democracy through a territorial reorganisation of France. The death toll of Communards in the final bloody week of the Commune was around 10,000, with some estimates even citing a higher figure of 20,000. Many of the victims were killed in mass shootings and revenge attacks. Photography played a decisive role in their deaths, because the government and army used photographs taken of the Commune to identify numerous participants. This is why the photographic medium became a pressure point for the uprising - not only did it transmit representations of revolutionary struggle, but later it also featured as a basic identification technique in the police archives. While in no doubt of photography's repressive potential, the rebels readily had their photographs taken while defending the barricades, and on one occasion even received orders to be on active duty at the fortifications for the mere purpose of a photo opportunity.
\end{abstract}

Baton raised to signal his troops (or to cue the photographer), he is held against the blank whiteness, transfixed, illuminated. A defiant insurgent? A playful poseur? An angel about to ascend to heaven? I look at this man and wonder what he expected to see when he faced the camera. When the shutter closed, did he feel history's force like a storm rushing against his angel-wings? ${ }^{1}$

For many Communards, it was the first time they had posed for a photograph. They naively believed in the immortality that photography offered, and they wanted to be recorded. Indeed, photography in the Second French Empire, as Roland Barthes noted, was intricately linked with public identity, civic status and social belonging. It featured primarily among the bourgeoisie, ${ }^{2}$ and then became accessible to the lower classes for a time. The tragedy of

\footnotetext{
1 Jeannene M. Przyblyski, 'Revolution at a Standstill: Photography and the Paris Commune of 1871', in: Yale French Studies 101: Fragments of a Revolution, New Haven 2001, p. 55.

2 Ibid., p. 63.
} 


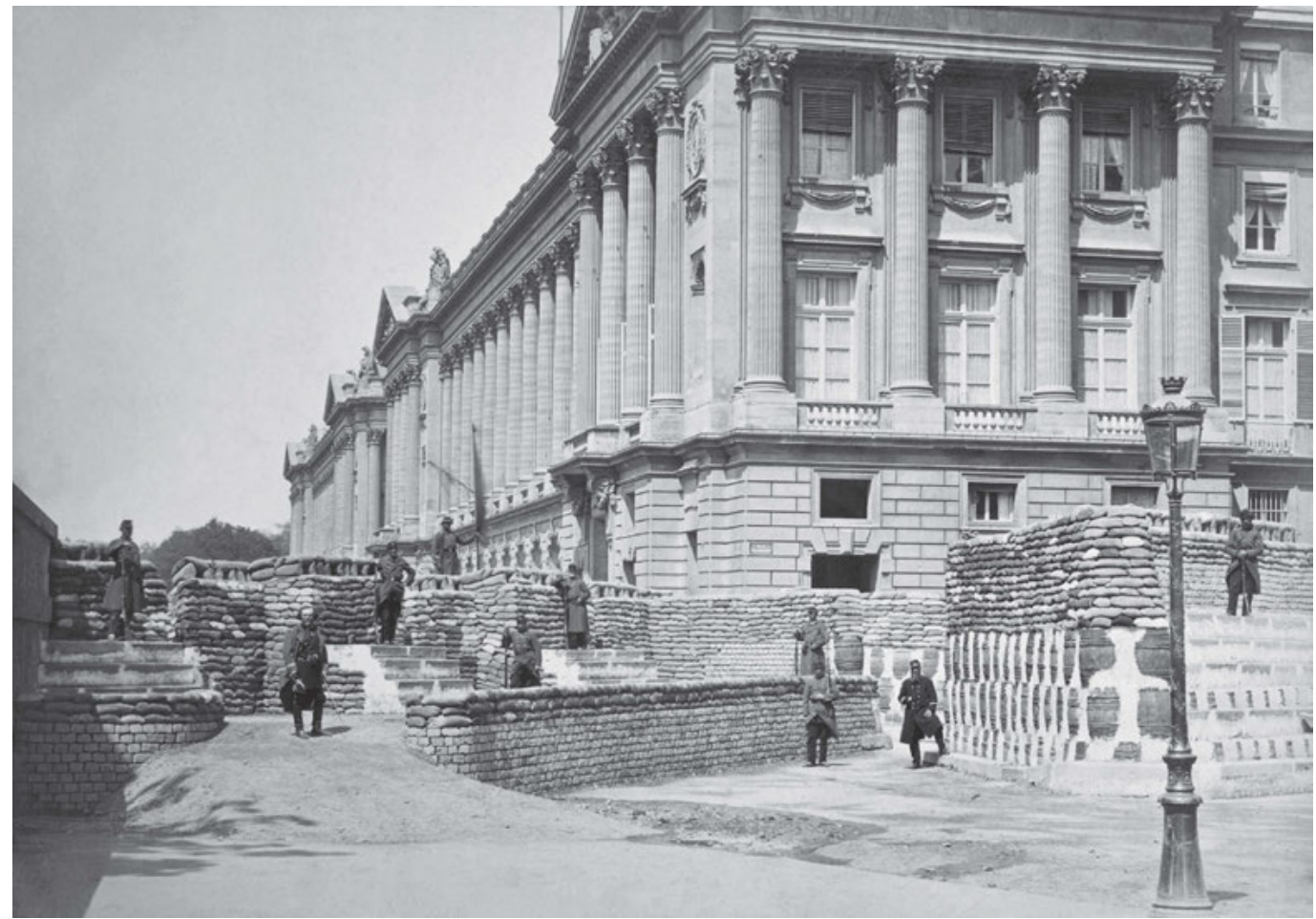

Barricades during the Paris Commune near the Hôtel de la Marine (French Navy Headquarters) and Hôtel de Crillon, 1871. Photo: Auguste Hippolyte Collard. The Metropolitan Museum of Art, 270204, The Elisha Whittelsey Collection

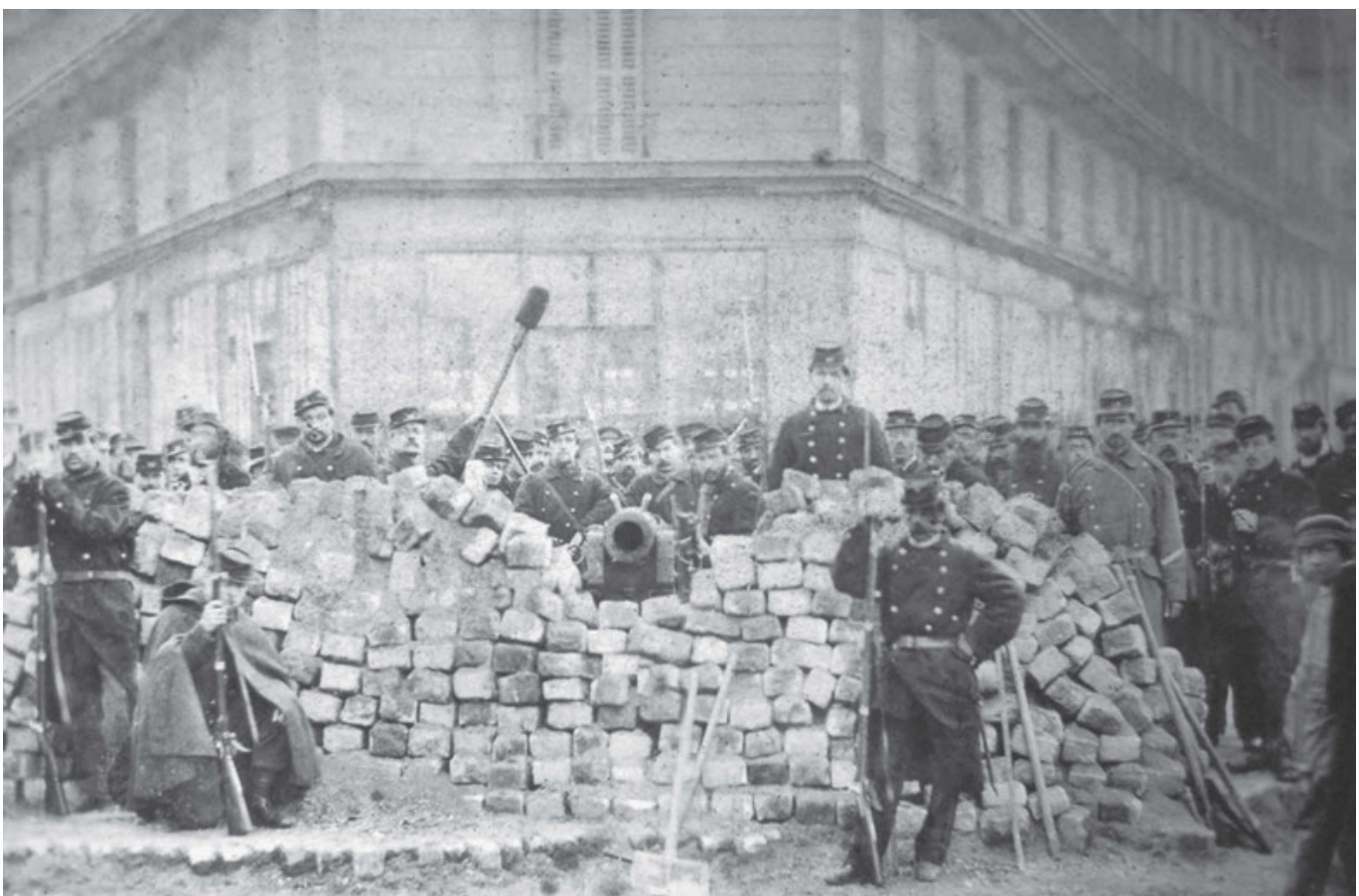

The barricade on the corner of the Boulevard Voltaire and the Boulevard Richard-Lenoir during the time of the 1871 Paris Commune. Photo: Bruno Braquehais. Bibliothèque historique de la Ville de Paris/Roger-Viollet. 
this chapter of history perhaps also lies in that yearning to be immortalised in a picture. The rebels lost the battle at the level of representation because of their desire for immortality.

Bruno Braquehais was one of the most active photographers of the Paris Commune, and his photographs aided the later identification of most Communards. While better-known today, Eugène Appert, the second Parisian photographer connected with the Commune, was not as active on the ground. However, to outflank rival photographers, he devised a more deceitful way of earning money. With the government's blessing, and fulfilling their needs as well as his, he photographed members of the Commune who had been caught and locked up. In return for his efforts, he gained unlimited authorial rights for further use of the photographs. As the public's desire for these photographs grew, Appert chose to reconstruct certain events, and even engaged professional actors and actresses to do so. For the first time in history, photographs of people interacting were staged. On the one hand, this served the government's propaganda needs, while on the other, it helped the author make a profit. Thus Appert can lay claim to the dubious honour of making the first staged photographs in the history of photography. In doing so, he participated in the creation of anticommunist propaganda and contributed to the repression of captured Communards. ${ }^{3}$ In the original photographs, the imprisoned Commune members have tired and exhausted expressions on their faces after defeat - their clothes are dirty and their humiliation obvious. The portrait of Louis Rossel, a former army colonel who switched sides at the very start of the rebellion and served as the Communards' Minister of War, was photographed by Appert in prison in September 1871, two months before his execution. Appert later superimposed Rossel's head onto the body of another person photographed in his studio, ${ }^{4}$ and even went as far as to re-enact the scene of Rossel's execution. Little burdened by ethical questions, Eugène Appert found his way into the history of photography not because of his photographic and artistic importance, but because he was the first to use a camera manipulatively. He skilfully deceived a then naiver viewing public, which assumed photographs were a visual record of historical fact. His work marks the beginning of manipulation by photographic means.

\section{Appert's composite portraits strike me as even more insidious, not merely because they are falsified images masquerading as real, but because they potentially expose all photographic por- traits as fictions, unmasking even the fragile decorum of the Communard prisoners as little more than disguise. ${ }^{5}$}

Although the invention of cartes de visite in 1854 made photography accessible to many, photography remained beyond the reach of the working class and the urban poor. Culture and art were intended principally for the bourgeoisie, which had time for leisure, whereas the working class did not. The inventor of the photographic carte de visite, André-Adolphe-

\footnotetext{
3 Peter Field, 'History in the Making', in: e-flux journal, 18, 2010, URL: http://worker01.e-flux.com/pdf/article_161.pdf (accessed 8 October 2016).

4 Przyblyski 2001 (see note 1), p. 67.

5 Ibid., p. 77.
} 


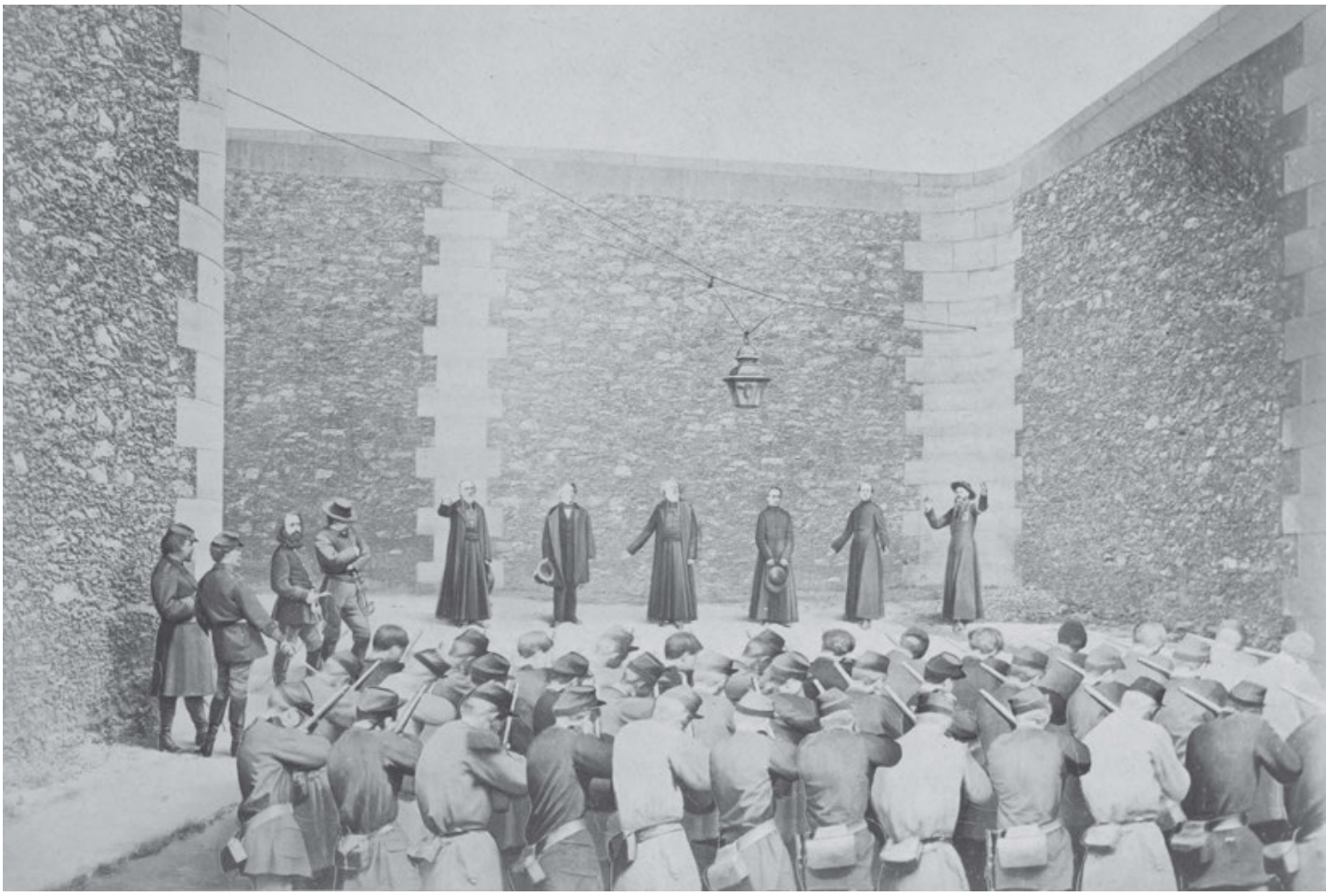

The execution of hostages by firing squad, La Roquette Prison, 24 May 1871. The Metropolitan Museum of Art, 302335, Joyce F. Menschel Photography Library Fund, 2012.

Eugène Disdéri, also photographed members of the Paris Commune on the barricades, as well as their corpses. For Versailles, Disdéri's photographs represent rebels who got the justice they deserved, while for members of the Commune, they were proof of an incredibly brutal revenge and trophy photographs of a criminal act.

During the time of the Paris Commune, photographs of the rebels were published in all newspapers, a tactic also used by the police and army to identify revolutionaries. This was because the police archive, located in the city hall, the Hôtel de Ville, had been destroyed in a blaze. The new chief of criminal identification for the Parisian police, Alphonse Bertillon, set about creating a new police archive. By 1883, he had developed an anthropometric system and statistical parameters for an archive of criminal records. Bertillon's archive was the blueprint for the modern police record and the criminal register. The method of taking one frontal and one profile shot of arrested persons ('mugshots') has remained the police standard to this day. This method has also influenced the development of contemporary biometric methods of identification and surveillance. Bertillon's system laid the groundwork for the method of record-keeping based on biological determinism and eugenics devised by his English contemporary, Francis Galton, the inventor of composite photographic portraits and of fingerprinting as a means of gaining a unique representation of a person. Galton claimed that through photography alone, the number of people sentenced to live in poverty and squalor could be reduced, with no further increase in the number of urban poor. He drew on racist theories of the superiority of the white 'race' over black Africans, as well 
as of the bourgeoisie over the proletariat. ${ }^{6}$ Galton's composite portraits set the scene for the creation of an essentialist anthropology of race and the formulation of portraits of 'inferior' races and nations.

This marriage of photography and eugenics to serve theories of race roughly coincided with the birth of Nazism and partly explains why the Nazis, once in power, destroyed many of August Sander's photographs taken for his typological study Face of Our Time, which contained hundreds of portrait photographs that did not fit in with the Aryan paradigm.

Photography became a powerful and influential propaganda weapon after the Nazis came to power in 1933. It was misused to establish new theories that were primarily antisemitic In May 1939, the exhibition Das körperliche und seelische Erscheinungsbild der Juden (The Physical and Spiritual Appearance of the Jews) went on show at Vienna's Naturhistorisches Museum. The exhibition was opened by Dr Josef Wastl, head of the museum's department of anthropology and member of the Nazi Party from 1932, long before the Anschluss. In contrast to the already well-known exhibition Der Ewige Jude (The Eternal Jew) of 1937, which presented so-called 'degenerate art' by Jewish modern artists, the later exhibition at the museum of natural history justified its pseudo-scientific approach through the abundant use of photographic material from police archives and strived to render visible the 'Judas face' supposedly common to Jews. ${ }^{7}$ In September 1939, Wastl went one step further and carried out his racist research on 440 Jews imprisoned at a football stadium in Vienna. ${ }^{8}$ Reporting on a subsequent Viennese exhibition on the 'battle zone in the southeast' that featured contributions by collaborationist-ruled Serbia, in its edition of 1 July 1944, the Srpski narod (Serbian People) wrote that the exhibition included 'trophies of communist-Partisan gangs' and photographs of killed Partisans, as well as images of Partisans whose detachments had been destroyed by Serbian nationalists. ${ }^{9}$

Bertillon's archive paved the way for eugenics. And eugenics, in turn, formed the foundation of the Nazis' race theories, which Slavs, in joining the Yugoslav Partisan movement, fought against and which were ultimately used to justify their murder. However, the Partisan movement also gave rise to its own special artistic and photographic narrative. Partisans knew from the beginning of the armed struggle that victory also demanded gains in the battleground of representation. A total of seventy years after the Paris Commune, the flag under which Communards had fought was borne aloft once again by Partisans when they set off on their struggle for freedom. ${ }^{10}$ From the time of the Paris Commune until more recently, social movements have typically been in a weak position compared with the dominant system that controls the production and distribution channels of propaganda. The

\footnotetext{
6 Davor Konjikušić, 'Fotografija i moć', Master's thesis, Akademija dramske umjetnosti, Zagreb 2014, pp. 23-24.

7 Andras Renyi, 'Time to Gaze', in: Col Tempo. The W. Project, exh. cat. Műcsarnok Budapest 2009, URL: http://coltempo.hu/catalog/time_to_gaze.html (accessed 11 May 2021).

8 Margit Berner, 'The Nazi Period Collections of Physical Anthropology in the Museum of Natural History', in: idem, URL: http:// coltempo.hu/catalog/margit_berner.html (accessed 11 May 2021).

9 Olivera Milosavljević, 'Potisnuta istina. Kolaboracija u Srbiji 1941-1944', in: Ogledi, 7, Belgrade 2006, p. 30.

10 Koča Popović, Beleške uz ratovanje, Belgrade 1988, p. 28.
} 
members of the Paris Commune unfortunately realised this too late, and they ended up paying with their lives. Seeing is always mediated by representation and ideology, ${ }^{11}$ which is why the Partisans soon realised that they would also have to win the war of representation. 